\title{
СОСТОЯНИЕ ДИСЦИПЛИНЫ
}

\section{Б.И. МАКАРЕНКО* \\ ВЫБОРЫ: ФУНКЦИИ И ВЛИЯНИЕ НА ПОЛИТИЧЕСКИЕ ИНСТИТУТЫ}

Аннотация. В статье рассматриваются различные функции выборов и оказываемое ими влияние на различные институциональные характеристики политического режима: 1) ритуальное оформление политической нации, легитимация всех политических институтов и профессионального класса политиков; 2) оформление представительства граждан во власти через посредующие институты; 3) формирование системы сдержек и противовесов, управления политическими конфликтами. Анализируются также формат ответственности избранных политиков перед обществом, явления политического популизма, новые феномены в отношениях между политическими партиями и избирателями. В заключение автор кратко рассматривает особенности проявления данных функций выборов в России.

Ключевые слова: выборы; демократия; институты; политические партии; политический режим.

Для иитирования: Макаренко Б.И. Выборы: Функции и влияние на политические институты // Политическая наука. - М., 2019. - № 1. - С. 13-32. DOI: $10.31249 /$ poln/2019.01.01

* Макаренко Борис Игоревич, кандидат политических наук, профессор Национального исследовательского университета Высшая школа экономики, президент Фонда «Центр политических технологий» (Москва, Россия), e-mail: bmakarenko@yandex.ru

Makarenko Boris, National Research University Higher School of Economics; Center for Political Technologies (Moscow, Russia), e-mail: bmakarenko@yandex.ru

(C) Макаренко Б.И.

DOI: $10.31249 /$ poln/2019.01.01 


\section{B.I. Makarenko \\ Elections: Functions and impact on political institutions}

Abstract. The article analyses various aspects of impact that elections produce on political institutions. In includes "ritual" function of elections which produce a political nation, legitimation of all political institutions and professional political class. Another function is representation of citizens in the political domain by virtue of intermediary political institutions. Yet another, is building a system of checks and balances and conflict management. Besides, the article discusses the problem of accountability of elected officials and the phenomenon of modern populism and other new trends in relations between parties and voters. The concluding chapter briefly touches upon the specific features and effects of elections in the Russian political system.

Keywords: elections; democracy; institutions; political parties; political regime.

For citation: Makarenko B.I. Elections: Functions and impact on political institutions // Political science (RU). - M., 2019 - N 1. - P. 13-32. DOI: $10.31249 /$ poln/2019.01.01

Бурная реакция российского политического класса и гражданского общества на итоги региональных выборов 9 сентября 2018 г. показала, что этот институт остается четким индикатором состояния общественного сознания. Эта реакция отражает основные институциональные функции выборов. Не только обыватели, но и политологи зачастую сводят их к периодическим голосованиям, определяющим расклад сил во властных институтах в соответствии с классическим определением Й. Шумпетера: «Такой политический порядок принятия решений, в которых люди обретают властные полномочия путем конкурентной борьбы за голоса избирателей» [Schumpeter, 1975, p. 250]. Но функции выборов не исчерпываются борьбой за власть. Даже минималистское определение «электоральной демократии» [Diamond, 2003, p. 8] подразумевает наличие в стране институтов и свобод, обеспечивающих относительное равенство условий для участия в выборах. Как отмечает А. Пшеворский, «для проведения выборов нужно нечто большее, чем выборы» [Przeworski, 1999, p. 24].

В данной статье мы рассматриваем, как различные функции выборов проявляются в различных типах политических режимов и какое влияние они (выборы) оказывают на политические институты. Это влияние не имеет одностороннего характера: сформированные по итогам выборов (или испытывающие косвенное влияние выборов) политические институты, в свою очередь, влияют на чест- 
ность и справедливость выборов, практику избирательных кампаний и шире - стиль публичной политики.

Ключевая роль выборов задается тем, что они являются главным каналом коммуникации власти и общества в сфере политического. Без выборов такая коммуникация возможна лишь там, где сакральность власти не ставится под сомнение - в теократии, абсолютной монархии или предельно жесткой диктатуре. В остальных случаях общество участвует посредством избирательных процедур в формировании, легитимации и отправлении власти. Это влияние может быть реальным, ограниченным или имитационным, как в однопартийных коммунистических или других диктаторских режимах; электорат может охватывать подавляющее большинство взрослого населения или ограничиваться жесткими сословными, имущественными и иными цензами. Но без такого волеизъявления в наши дни обходится абсолютное меньшинство политических режимов. Соответственно, и характер политического режима во многом зависит от институционального дизайна и характера выборов.

\section{Выборы как ритуал и легитимация режима}

Первая и главная функция выборов - ритуальная. Через совместное волеизъявление определяется и политическая нация, и ее правители. Приведем две цитаты из классиков. М. Эдельман: «Голосование - это единственная для большинства граждан форма участия в управлении страной... [Выборы] дают людям возможность... испытать чувство сопричастности [Edelman, 1964, p. 3]. Д. Растоу, описывая чувство национального единства как важнейшую и первую предпосылку демократии, поясняет: «Народ не может принимать решения, пока не решено, кто составляет этот народ» [Rustow, 1970, p. 356]. Голосование за общего для всех правителя или представительное собрание символизирует принадлежность людей к одной политии.

Подчеркнем: эти функции выборы выполняют во всех типах режимов, независимо от уровня конкурентности. Разница лишь в том, что в недемократических режимах функция ритуальности единственная, которая действует «в полную силу». 
В сегодняшней Москве ${ }^{1}$ граждане старше 55 лет, то есть голосовавшие еще в советские времена и составляющие $37 \%$ избирателей столицы, не просто проявляют более высокую электоральную активность: 55\% из них голосуют, как было принято в СССР, преимущественно в утренние часы; до полудня их доля вообее составляет 62-63\%. Это свидетельство «ритуальности» голосования.

Неконкурентные выборы выполняют также функцию легитимации власти, но специфическим способом. В конкурентных режимах легитимность власти утверждается посредством «прозрачной» электоральной борьбы - общество само определяет победителя из нескольких альтернатив. В жестких диктаторских режимах выборы носят откровенно «фасадный» характер, стабильность власти в них обеспечивается вертикалью военно-полицейских и штатских бюрократов или иных держателей властных ресурсов. В более «гибких» и современных авторитарных режимах диктаторы занимаются институциональной инженерией, чтобы выстроить, с одной стороны, управляемую элитную коалицию, а с другой - механизмы социальной мобилизации и обратной связи с обществом. Ресурсом стабильности для таких режимов служит высокий электоральный результат как с целью демонстрации своей силы лояльным избирателям, так и для внушения потенциальным оппонентам мысли о бесперспективности попыток бросить вызов [Magaloni, Kricheli, 2010; Magaloni, 2006].

Легитимация власти имеет еще одно измерение: выборы как процесс, организуемый государством и вовлекающий (по крайней мере, в идеале) всех взрослых граждан, придают легитимный статус «политиков» всем без исключения участникам. Их результаты это сертификация победителей как законных отправителей власти, a всех остальных - как не менее законных претендентов. В авторитарном режиме оппозиция либо запрещена (вспомним приписываемое Н. Бухарину высказывание: «У нас могут быть только две партии: одна у власти, другая в тюрьме»), либо подконтрольна власти полностью или частично. Там, где конкуренция свободна, проигравшие формируют оппозиционные фракции, критикуют власть, предлагают альтернативы правительственному курсу, с тем чтобы через несколько лет, по выражению А. Пшеворского, «попытать счастья вновь по тем же институциональным правилам, по

${ }^{1}$ Собственные данные автора, по данным экзитпола в Москве в 2018 г. 
которым они только что проиграли» [Przeworski, 1991, p. 26]. Легитимация всех участников выборов становится предпосылкой формирования профессионального политического класса.

В конкурентных режимах функции выборов не ограничиваются ритуалом политического участия и легитимации власти. Необходима, правда, важная оговорка: не всякое голосование представляет собой реальный выбор. И речь не только о неконкурентных выборах.

До Нового времени, секуляризировавшего общественнополитическую жизнь, доминировал политико-правовой принцип «единой божественной воли». Кажущийся демократическим принцип «Глас народа - глас Божий» на самом деле имел прямо противоположное значение: он возводил в абсолют принцип консенсусного решения, зафиксированный в римском праве: «Все, что в равной степени касается всех, должно быть одобрено всеми». На этом принципе основывалась легитимность монаршей власти, но также и, в большинстве случаев, практика выборов: избрание главы Римско-католической церкви (неспособность достичь консенсуса многократно порождала расколы и «антипап») или принцип абсолютного вето в законосовещательных сословных ассамблеях, когда один депутат мог заблокировать принятие решений, например кортесов Арагона и Каталонии и польского сейма [Colomer 2001, p. 74-80].

Абсолютизация неконкурентных волеизъявлений проявляется как рудимент в некоторых современных электоральных процедурах, например в принципе «императивного мандата» - принуждении избранного депутата строго следовать воле своих избирателей (реальной или искусственно выведенной) под угрозой отзыва или лишения мандата. Такой принцип действовал в большинстве стран коммунистического лагеря - начиная с СССР и заканчивая сегодняшними КНДР, Вьетнамом и Кубой. Изжитый в Европе, этот принцип действует в некоторых парламентских республиках с британской традицией (ЮАР, три государства Индостанского полуострова) - с тем обоснованием, что нарушение дисциплины голосования может привести к вотуму недоверия и падению правительства. 


\section{Общество и власть: Модель взаимодействия через выборы}

Изначально, в античных демократиях, практика выборов подразумевала прямое делегирование власти очным голосованием всех полноправных граждан полиса (мужчин) за кандидата на выборную должность. При этом не было ни подотчетности избранного, ни представляющих граждан посредующих институтов.

Современная трактовка выборов подразумевает не «прямую демократию» ${ }^{1}$, а представительство во власти через делегатов и институты. Свое приведенное выше определение Й. Шумпетер дополнил замечанием, что главная функция выборов - образовывать власть [Shumpeter, 1975, р. 272]. Казалось бы, это противоречит определению М. Эдельмана о «ритуальности участия» как главной функции выборов. На самом деле эти определения скорее дополняют друг друга, поскольку политическое участие должно порождать эффективное правительство.

Понимание необходимости институционализации власти и порядка ее формирования через выборы возникало постепенно. Первой ее формулировкой можно считать концепцию «смешанной власти» короля и сената в трактате Фомы Аквинского «Сумма теологии» (1274): «Королю дается власть над всеми, но наряду с ним существуют и другие власти, поскольку все наделены правом править и правила устанавливаются со всеобим участием» (цит. по: [Pasquino, 2015, p. 114]). В Новое время, особенно в эпоху Французской и Американской революций и появления первых современных представительных ассамблей, формируется концепция разделения властей, или концепция сдержек и противовесов. Известно рассуждение аббата Сийеса (1789) о том, что в «коммерческом» обществе (имеется в виду общество с развитым разделением труда) политика становится профессией [Ibid.], и это создает разделение труда между профессиональными политиками и массой избирателей, роль которых ограничивается делегированием своих представителей во власть. Равенство граждан в этом контексте по-

${ }^{1}$ Хотя в последние годы на волне подъема популизма и «новых» партий дискурс на эту тему возрождается. См.: [Бло, 2015; специальный выпуск журнала «Daedalus» (2017), посвященный делиберативной демократии]. 
нимается не как равное участие в отправлении власти, а как равный шанс повлиять на то, кто будет наделен властью.

Именно в это время начинается процесс формирования политических партий. Исследователи, в частности Г. Алмонд, Дж. Лапаломбара и М. Вейнер [Сравнительная политология... 2002; Political parties and, 1966], описывают его как цепочку причинно-следственных связей, схожую с той, которую отметил аббат Сийес: усложнение конфигурации интересов общества и элит, секуляризация общественной жизни, ослабление власти абсолютных монархов. Законодательная (выборная) власть обретает свою сферу компетенции, судебная власть становится независимой от других ветвей. Устойчивые общественно-политические размежевания приводят к становлению многопартийных систем [Lipset, Rokkan, 1967].

Принцип представительства, то есть делегирования полномочий, множественности властных институтов и разделения властей, становится основополагающим и понимается как функция выборов. А. Пшеворский и соавторы [Democracy and... 2000] дают определение следующих элементов представительной демократии: выборность исполнительной власти (всенародно или при посредстве всенародно избранного парламента), выборность парламента, наличие более чем одной партии, возможность сменяемости власти и опыт мирного отстранения правителей от власти через выборы.

Современная эпоха, если обратиться к концепции полиархии [Даль, 2010], дополняет этот набор другими качественными характеристиками: верховенство права, гражданские свободы (в первую очередь свобода самовыражения), инклюзивный характер активного избирательного права и наличие альтернативных и независимых источников информации.

Выборы в современных демократиях обеспечивают высокую степень представленности различных сегментов общества не только в парламентах, но и в исполнительной власти. По данным исследования в 36 странах, корреляция между ориентациями избирателей по шкале «левые - правые» и усредненной позицией партий, входящих в состав правительства, составляет $r=0,72$; еще выше корреляция между позицией правительства и входящих в него партий: $r=0,91$ [Dalton et al., 2011, p. 171-175]. В большинстве случаев это означает, что правительства представляют так называемого медианного избирателя, то есть экспертно оцененную медиану существующих в обществе политических предпочтений. 
Это наблюдение совпадает с подсчетами Х. Коломера по 451 выборам за период с 1945 по 2000 г.: 54\% выборов по мажоритарной системе в один тур давали кабинеты и президентов, представлявших медианного избирателя; для мажоритарной системы в два тура эта цифра составляла 73\%, для пропорциональной - 90\% [Colomer, 2001, p. 68].

\section{Политический режим и избирательная система: Как работают выборы}

В рамках одной статьи вряд ли возможен подробный разбор преимуществ и недостатков президентских и парламентских режимов, мажоритарных и пропорциональных избирательных систем. Между тем это имеет прямое отношение и к выборам, и к системе образуемых по их итогам институтов. Ограничимся лишь самыми важными замечаниями.

Со второй половины XX в. выбор избирательной системы перестал быть произвольным. Как отмечают исследователи [Демократизация, 2015, с. 394-397], при переходе от авторитаризма к демократии законодатель в большинстве случаев отдает предпочтение пропорциональной или смешанной избирательной системе. Исключение составляют страны, входившие в британскую колониальную империю, а также ряд постсоветских государств (Абхазия, Азербайджан, Белоруссия, Туркменистан и Узбекистан). Первые сохранили приверженность давней традиции, у вторых даже не ставилось задачи построить конкурентную политическую систему.

Пропорциональная система не только позволяет точнее учитывать предпочтения избирателей, но и не завышает результат сильнейшего игрока, не провоцирует биполярного противостояния, особенно опасного в переходных обществах, лишенных возможности расширять активное избирательное право постепенно [Colomer, 2001, p. 41-45]. Такие системы порождают многопартийность, а также принуждают конкурирующие силы к поиску компромиссов - ведь для принятия политических решений зачастую необходима коалиция партий.

Однако для стран с недавним опытом плюрализма пропорциональные системы имеют один существенный недостаток: «В них отсутствие опыта предыдущих выборов лишает лидеров 
партий возможности реалистически оценить свои шансы на успех» [Taagapera, 1997]. В результате в первом-втором цикле конкурентных выборов участвуют множество партий, большинство из которых получает предельно низкие результаты. Со временем, конечно, число участников сокращается до разумных пределов.

Выборами во многом определяется и специфика государственного строя. Всенародные выборы президента - неважно, в один или два тура, - по определению имеют мажоритарный характер и, соответственно, влекут риск завышения результата победителя, который «получает всё». Это имеет важное следствие для устойчивости демократии. Баланс сдержек и противовесов между всенародно избранным президентом, кабинетом министров и парламентом имеет четкое количественное измерение. Проследим его путем наложения классификации политических режимов Шугарта и Кэри [Shugart, Carey, 1992, p. 18-27] и Индекса полномочий парламента [Fish, Kroening, 2009] (расчет сделан по 51 стране, большинство из которых перешли к многопартийности после Второй мировой войны).

Таблица

\section{Корреляция типа политического режима с объемом полномочий парламента}

\begin{tabular}{|l|c|c|}
\hline \multicolumn{1}{|c|}{ Тип политического режима } & $\begin{array}{c}\text { Кол-во } \\
\text { стран }\end{array}$ & $\begin{array}{c}\text { Среднее арифметическое } \\
\text { значение индекса полномочий парламента }\end{array}$ \\
\hline Президентский & 13 & 43,7 \\
\hline Президентско-парламентский & 5 & 60,8 \\
\hline Премьер-президентский & 12 & 65,6 \\
\hline Парламентский & 21 & 72,5 \\
\hline
\end{tabular}

Как следует из табл., объем полномочий парламента находится в обратной зависимости от широты полномочий президента. Примечательно, что последние два места по показателю полномочий парламента занимают две постсоветские республики, в которых партийные системы фактически не сложились (Белоруссия и Туркменистан), и лишь в одном постсоветском государстве (Молдове) этот показатель, как и в западных посткоммунистических странах, выше среднего по выборке.

М. Шугарт и Дж. Кэри отмечали, что в режимах с широкими президентскими полномочиями высок риск отката к авторитаризму, там же, где полномочия президента и парламента сбалансиро- 
ваны, демократические режимы, напротив, максимально устойчивы [Shugart, Carey, 1992, p. 176-177]. Специалист по «полупрезидентским режимам» Р. Элджи указывает на риски дестабилизации в ситуациях, когда всенародно избранный президент вынужден иметь дело с оппозиционным парламентским большинством. «Сосуществование» же с кабинетом министров, сформированным оппозицией, по его оценкам, лишь в исключительных случаях приводит к коллапсу (правда, среди таких исключений - установление нацистского режима в Веймарской Германии), зато попытки президента править через «кабинет меньшинства» чреваты крушением демократии почти в 40\% случаев [Elgie, 2008].

А. Лейпхарт, резюмируя обзор институтов в 36 демократиях, подчеркивает, что пропорциональная избирательная система и парламентская республика чаще порождают консенсусную модель политики и отличаются большей устойчивостью [Lijphart, 1999, p. 302-305]. Обратим внимание на то, что оба этих параметра задаются выборами.

\section{Конкурентность выборов как институциональная характеристика}

Конкурентность и сменяемость власти через выборы - относительно недавнее явление [Przeworski, 2015, p. 221]. Эта функция выборов не универсальна, но именно она порождает институционально оформленную демократию.

Размежевание политического класса на партии порождает по крайней мере гипотетическую вероятность утраты власти в результате выборов. Тем самым создается первый элемент системы сдержек и противовесов: оппозиция сдерживает власть. Это принуждает правящую партию к ответственному поведению и подотчетности. Не менее важен и другой эффект конкуренции: она принуждает политический класс избегать крайностей и радикальных решений. Оснований для такого поведения несколько: во-первых, при высоком уровне конкуренции партиям необходимо завоевывать «медианного» избирателя, который хоть и не тождественен «центристскому», но в любом случае не склонен к радикализму (во всяком случае в стабильном обществе). 
Во-вторых, в избирательных кампаниях неизбежно присутствуют так называемые поливалентные темы (valence issues) [Stokes, 1963] - вопросы, по которым все общество придерживается общей позиции (преступность, коррупция и т.п.). В таких вопросах партии должны доказывать свою способность предложить лучшее решение проблем.

В-третьих, сменяемость власти заставляет партии планировать долгосрочные стратегии с учетом ее осознания: резкие колебания политического курса при смене правительства были бы заведомо контропродуктивны, а в ряде областей (социальная политика, страховая и пенсионная система) - и вовсе разрушительны.

С учетом этих факторов основные политические игроки вынуждены искать компромиссы и управлять конфликтами. В этом смысл теории «ограниченной неопределенности» [Schmitter, Karl, 1991]. «Ограничители» - это уважение к процедурам, недопустимость таких изменений, которые сделали бы невозможными следующий раунд конкурентных выборов, соблюдение гражданских прав и свобод, уважение прав собственности и т.п. «Ограниченная неопределенность» ставит вопрос о роли гражданской политической культуры. Эта теория восходит к «условиям успеха демократии» И. Шумпетера, среди которых - «качество человеческого материала», «дух добросовестного служения», «демократический самоконтроль» [Schumpeter, 1975, p. 292]. Важно, что Ф. Шмиттер и T. Карл считают формирование правил «ограниченной неопределенности» не предпосылкой, а продуктом конкурентной политики: «Их укоренение и вытекающее из них гражданское согласие и ограниченная неопределенность может занять целые поколения и возникнуть в результате взаимодействия антагонистических и взаимно подозрительных субъектов политики» [Schmitter, Karl, 1991, p. 85].

Это, однако, означает, что на ранних этапах конкурентной политики выборы могут повлиять на политический режим в прямо противоположном направлении: если сегменты общества стоят на антагонистических позициях, если гражданская культура компромисса отсутствует, выявление выборами «арифметического превосходства» одной политической силы может спровоцировать ее на монополизацию власти, разрушение демократических процедур, в том числе самих выборов. Наиболее очевидный пример победа германских нацистов в 1933 г. Другой пример - первые многопартийные выборы в Алжире в декабре 1991 г., когда в пер- 
вом туре лидерами во многих округах оказались радикальные исламисты; в итоге произошел военный переворот, и второй тур был отменен; за этим последовала десятилетняя гражданская война, число жертв которой оценивается в 100 тыс. человек. Более мягкая форма «неработающей конкуренции» - изменение электоральных правил победителями первых выборов: продление через конституционные поправки и референдумы сроков полномочий главы государства, отмена ограничений на количество сроков у власти таким путем пошли Беларусь и государства Центральной Азии.

Еще один требующий внимания момент - масштаб «ограничений неопределенности». Ф. Шмиттер и Т. Карл указывают, что в разных странах эти рамки складываются по-разному. В большинстве случаев этот масштаб относительно невелик и предсказуем. Наглядный пример последних лет: Д. Трампу даже при лояльном большинстве в обеих палатах конгресса удалось достаточно радикально реформировать налоговую систему, но он так и не смог отменить систему медицинского страхования, введенную его предшественником, - по причине указанной выше «институциональной инерционности» страховых и пенсионных систем. Одно из нечастых, но наглядных исключений - последствия перехода власти от правоцентристской к левоцентристской партии в Испании после драматичных выборов 2004 г.: вывод испанского контингента из Ирака, резкое повышение социальных расходов, легализация однополых браков. Эти меры были реализованы при электоральных подвижках всего на 8 процентных пунктов.

\section{Подъем популизма и другие новые феномены выборов}

Подъем популизма в большинстве стран Запада принято считать кризисным явлением, следствием падения качества демократических процедур и - что важно для анализа выборов - возвратом к плебисцитарной модели голосования. Апеллируя к массе, большинству, популизм стремится наполнить антиистеблишментным нарративом всю политическую арену, освободить ее от всех посредующих институтов (в первую очередь партий) и процедур [Urbinati, 2014, p. 131-145]. Популистская волна пришлась на период принципиального усложнения структуры общественнополитических размежеваний, порожденного глобализацией: новые 
партии привлекают голоса общественных страт, как воспринявших эти ценности, так и ставших жертвами глобализационных процессов. Выборы становятся не просто «барометром» этих настроений, но и каналом представления интересов соответствующих социальных групп, что выражается в заметном росте электората новых партий и их парламентского представительства [Макаренко, 2018, c. 143-144].

В ряде стран антиистеблишментные силы приходят к власти (СИРИЗА в Греции, Фидес в Венгрии, «Право и справедливость» в Польше, Д. Трамп в США), но чаще просто входят в состав правящей коалиции (Австрия, Швеция, Финляндия, Дания). Для оценки последствий этого явления потребуется время, но уже сейчас можно сказать, что в новых, не успевших пройти полную консолидацию, демократиях (Польша и Венгрия) популистская власть действительно демонтировала часть системы сдержек и противовесов, присущих современному демократическому устройству (реформа высших судебных инстанций, ограничение свободы СМИ). В «старых» демократиях система институтов оказалась в состоянии «ассимилировать» популизм: популистская партия оказывается в роли младшего партнера в коалиции, влияет на правительственный курс (например, по миграционной политике), но в целом демократический характер политии сохраняется, либо популистский лидер вынужден считаться с системой сдержек и противовесов (Д. Трамп в США). Еще более интересен кейс Греции, где СИРИЗА пришла к власти на евроскептических лозунгах, но именно ее правительству пришлось достигать соглашения с ЕС о порядке урегулирования долгов перед европейскими партнерами.

Как минимум в двух странах ответом истеблишмента на популистский вызов стало выдвижение новых политических лидеров, которые имитировали популистский стиль и вели свои кампании под знаменем «обновления власти»: во Франции, где Э. Макрон обошел представителей как правого (Национальный фронт М. Ле Пен), так и левого («Непокоренная Франция» Ж-Л. Меланшона) популизма, и в Австрии, где победил лидер правоцентристской Народной партии С. Курц.

Другой феномен связан с партиями, которые добиваются значимого успеха на выборах, но отвергаются как потенциальные партнеры большей частью истеблишмента, оказываясь тем самым вне «национального консенсуса». Это партии, антагонистичные 
всему истеблишменту, а потому, согласно классической теории партийных систем, не обладающие «коалиционным потенциалом» [Sartori, 1976].

Именно в такой роли с конца Второй мировой войны и до начала 1990-х пребывала Коммунистическая партия Италии, занимавшая обычно второе место на общенациональных выборах, но ни разу не попадавшая в состав коалиционных кабинетов. В современной Европе это либо правые популисты (Национальный фронт во Франции, Партия свободы в Нидерландах), либо партии, воспринимаемые как наследницы коммунистического режима («Согласие» в Латвии, Компартия Богемии и Моравии в Чехии). В Германии усиление партий обоих типов («Левые» и «Альтернатива для Германии» заняли в бундестаге 22,6\% мест) привело в 2017 г. к затяжному кризису с формированием правительства. Между тем в XXI в. средний результат таких партий составлял $11-14 \%$ (у «Согласия» $-27 \%)^{1}$.

Еще одно связанное с выборами новшество - участие массового избирателя в выдвижении кандидатов на выборные должности. До недавнего времени этот процесс оставался внутренним делом самих партий. Исключение составляли лишь США, где отсутствует институт формального партийного членства, зато избиратели регистрируются как сторонники одной из двух ведущих партий или независимые. За более чем столетие привлечение избирателей к первичным выборам (праймериз) стало непременной процедурой.

В настоящее время процедура открытых для широкого круга избирателей праймериз практикуется во Франции, Великобритании, Канаде, Австралии. В Аргентине и Уругвае участие в праймериз обязательно для избирателей [Институт проведения... 2016]. Опыт праймериз весьма противоречив. С одной стороны, такая избирательная процедура демократизирует одно из самых главных «таинств» выборов - выдвижение кандидатов. С другой стороны, даже отлаженная американская система чревата рисками победы радикалов, которым легче заручиться поддержкой партийного актива, тогда как медианный массовый избиратель более склонен к умеренной позиции. В Европе же это проявляется с большей силой, что продемонстрировали во Франции праймериз «республиканцев» и Социалистической партии перед президентскими выбо-

${ }^{1}$ Собственные расчеты автора по базе данных http://psephos.adam-carr.net/ 
рами 2017 г.: в итоге их победители не прошли даже во второй тур голосования [Бунин, 2018]. Как всякий институт, имеющий отношение к выборам, праймериз должны быть осмыслены и «освоены» и элитами, и электоратом.

\section{Выборы и ответственность власти}

Одна из ключевых характеристик демократического режима ответственность власти перед избирателями. Однако если, как описано выше, участие граждан в политике ограничивается голосованием, как такая ответственность проявляется институционально? Как отмечают исследователи, «общая теория политической подотчетности власти, которая объясняла бы, как именно работают механизмы привлечения к ответственности или уклонения от нее, практически отсутствует» [Achen, Bartels, 2004].

Разумеется, главный механизм такой ответственности - перевыборы, на которых избиратель может отдать предпочтение оппозиции, осуществив «отстранение от власти негодяев». Однако между выборами этот механизм работает только в одном смысле: «заставляет инкумбентов нервничать», то есть вынуждает власть не уклоняться от выполнения предвыборных обещаний, стремиться сделать эффективной свою деятельность, не допустить коррупционных и иных скандалов. Другими словами, каналы отчетности носят преимущественно односторонний характер: избиратель может воздействовать на власть лишь необязывающими процедурами - петициями, письмами депутатам, дискуссиями на очных встречах.

Трудно вынести однозначное суждение и о том, «наказывает» ли избиратель политиков за неэффективность. Х-М. Мараваль приводит данные по 22 развитым странам ОЭСР за период с 1945 г. до конца первого десятилетия XXI в.: правящие партии терпели поражение на 131 выборах из 359 [Maraval, 2015, p. 156]. В годы выборов средний темп роста экономики составлял 2,2\%, средний уровень безработицы - 5,9, тогда как средние для всей выборки показатели были лишь чуть ниже - 2,7 и 5,5\%, то есть однозначной корреляции между поражением инкумбентов и неблагоприятными тенденциями в социально-экономическом положении не прослеживалось. 
Приведенные данные не означают отсутствия механизма отстранения от власти неэффективных политиков. Так, на первых после экономического кризиса 2008-2009 гг. выборах поражение потерпели правящие партии практически во всех старых членах ОЭСР. Косвенным следствием кризиса стало и снижение популярности право- и левоцентристских партий, составлявших ядро сменявших друг друга коалиций, - их сочли ответственными за «глобалистский» курс, приведший к кризису.

Еще более очевидный сценарий «наказания за безответственность» складывается в ситуациях, когда власть совершает деяние, воспринимаемое обществом как заведомая ложь и / или оскорбление. Наглядный пример - упомянутые выше «опрокидывающие выборы» в Испании в 2004 г. Почти до самого финиша избирательной кампании правящая Народная партия и оппозиционные социалисты имели практически равные рейтинги. Все изменили случившийся за несколько дней до выборов теракт на мадридском вокзале и неуклюжая попытка правительства обвинить в нем баскских сепаратистов, с тем чтобы отвести от себя ответственность за участие страны в коалиции, ведущей войну в Ираке. В итоге социалисты опередили инкумбента на 5\% и сформировали правительство.

\section{Вместо заключения: Российский опыт выборов}

Мы намеренно воздерживались от разбора отечественного электорального опыта. Очевидно, что этот опыт подтверждает практически всё, что сказано о «ритуальной» и легитимизирующей роли выборов, тогда как конкурентной стороны касается лишь в ограниченном объеме. И все же было бы неверно давать этому опыту сугубо негативную оценку.

Во-первых, выборы сыграли роль главного механизма транзита от посттоталитарного СССР к сегодняшней России. Особенность нашей страны в том, что такие «конституирующие выборы» фактически стали многоэтапными - от первых конкурентных выборов парламентов СССР (1989) и РСФСР (1990) - через выборы и референдумы 1991-1993 гг. и вплоть до 12 декабря 1993 г., когда одновременно прошли референдум по Конституции и первые выборы Государственной думы [Makarenko, 2015, 132-133]. Принцип выборности власти на всех уровнях неукоснительно соблюдается 
уже четверть века. Искушения отменить или «перенести» выборы имели место и в 1990-е годы, и после неожиданных для власти результатов сентября 2018 г., однако не реализовались тогда и, скорее всего, не реализуются и теперь: Кремль неоднократно подтверждал, что прозрачность и легитимность электоральных процедур является для него императивом.

Во-вторых, как и во всех посткоммунистических странах, в России не произошло полноценного размежевания сегментов общества, порождающего стабильные политические партии. Даже на западе посткоммунистического пространства, где сменяемость власти через выборы стала привычной, а качество электоральных процедур оценивается высоко, волатильность партийных систем значительно выше, чем в «старых демократиях». Однако в России сложилась партийная система и сформировался профессиональный депутатский корпус, ставший неотъемлемой частью политического класса.

В первом десятилетии нового века регулирование электоральных процедур и партийной системы последовательно приобретало все большую жесткость. Однако именно реакция общества на результаты думских выборов в декабре 2011 г. послала сигнал о том, что столь «зарегулированная» система не только не обеспечивает «обратной связи», но и подрывает легитимность власти, равно как нивелирует «ритуальную функцию».

В 2012 г. законодательство о выборах и партиях было частично либерализировано, а главное - изменилось целеполагание: приоритетом стала прозрачность и легитимность выборов, недопущение поводов для массовых протестов. Эффект этих действий неоднозначен. Ритуальная функция выборов практически восстановилась, что ярко проявилось на президентских выборах 2018 г. К прозрачности и легитимности также гораздо меньше претензий, чем семь лет назад, о чем свидетельствуют результаты опросов общественного мнения [«Выборы - 2018: Аналитический мониторинг»... 2018].

Состояние партийной системы практически единодушно признается кризисным, и реальных сдвигов за последние годы не наблюдается. Конкурентность выборов вплоть до осени 2018 г. оставалась невысокой, а появление десятков новых партий практически не повлияло на ее уровень. Соответственно, невелико ее воздействие и на развитие институтов, связанных с конкурентно- 
стью выборов. Снижение рейтингов провластных фигур и партии «Единая Россия» на фоне непопулярных реформ 2018 г. отразилось на их результатах, однако от долгосрочных прогнозов мы бы предпочли воздержаться: проведение непопулярных реформ в начале электорального цикла - привычная тактика демократических политиков, что подтверждают, например, действия Э. Макрона, который в первые месяцы после выборов также существенно потерял в рейтинге.

Неоднозначность нынешней ситуации свидетельствует об одном: становление института выборов и их полноценное влияние на другие государственные и общественные институты - процесс сложный и небыстрый. В России он тоже потребует значительного исторического времени.

\section{Список литературы}

Бло И. Прямая демократия: Единственный шанс для человечества. - М.: Книжный мир, 2015. - 304 с. - (Серия «Демократия XXI века»).

Бунин И.М. Выборы Макрона или Выбор Франции: Французская политика в 2017-2018 годах. - [М.: Московская школа гражданского просвещения]. - готовится к печати.

«Выборы - 2018: Аналитический мониторинг». Старт избирательной кампании: Конфигурация политических сил / Центр политических технологий. - М., 2018. Режим доступа: http://politcom.ru/22910.html (Дата посещения: 12.11.2018.)

Даль Р. Полиархия: Участие и оппозиция / пер. с англ. под ред. С. Деникиной, В. Барановой. - М.: Изд-во ГУ ВШЭ, 2010. - 288 с.

Демократизация: Учеб. пособие / Под редакцией К.В. Харпфера и др.; пер. с англ. под науч. ред. М. Г. Миронюка. - М.: Изд-во ВШЭ, 2015. - 708 с.

Институт проведения предварительных выборов: Мировой опыт / Минченкоконсалтинг. - М., 2016. - Режим доступа: http://www.minchenko.ru/netcat_files/ File/Primaries\%2025_05\%20full.pdf (Дата посещения: 02.11.2018.)

Макаренко Б.И. Теория партийных систем полвека спустя // Политическая наука. М., 2018. - № 1. - С. 122-147.

Сравнительная политология сегодня: Мировой обзор: Учебное пособие / Алмонд Г., Пауэлл Д., Стром К., Далтон Р.; под ред. М.В. Ильина, А.Ю. Мельвиля. - М.: Аспект Пресс, 2002. - 537 с.

Achen Ch., Bartels L. Blind retrospection: Electoral responses to drought, flu and shark attacks. - Madrid: Instituto Juan March, 2004. - (Working Paper; 2004/199). Mode of access: https://www.ethz.ch/content/dam/ethz/special-interest/gess/cis/ international-relations-dam/Teaching/pwgrundlagenopenaccess/Weitere/ AchenBartels.pdf (Accessed: 02.11.2018.) 
Colomer J. Political institutions: Democracy and social choice. - Oxford: Oxford univ. press, 2001. $-266 \mathrm{p}$.

Dalton R., Farrell D., McAllister I. Political parties and democratic linkage: How parties organize democracy. - Oxford: Oxford univ. press, 2011. - $238 \mathrm{p}$.

Democracy and development: Political institutions and well-being in the world, 19501990 / Przeworski A., Alvarez M., Cheibub J.A., Limongi F. - N.Y.: Cambridge univ. press, $2000 .-336 \mathrm{p}$.

Diamond L. Can the whole world become democratic? Democracy, development, and international politics / Center for study of democracy. - Irvine: University of California, 2003. - (Paper 03'05). - Mode of access: https://homepage.univie.ac.at/Vedran.Dzihic/ diamond 2004.pdf (Accessed: 02.11.2018.)

Edelman M. The symbolic uses of politics. - Urbana: University of Illinois Press, 1964. $164 \mathrm{p}$.

Elgie R. The perils of semi-presidentialism. Are they exaggerated? // Democratization. Wash., 2008. - Vol. 15, N 1. - P. 49-66.

Lijphart A. Patterns of democracy: Government forms and performance in thirty-six countries. - New Heaven: Yale univ. press, 1999. - 348 p.

Fish S., Kroening M. The handbook of national legislatures: A global survey. - Cambridge: Cambridge univ. press, 2009. $-800 \mathrm{p}$.

Lipset S.M., Rokkan S. Cleavage structures, party systems, and voter alignments: An introduction // Party systems and voter alignments: Cross-national perspectives. N.Y.; L.: The free press: Collier-MacMillan ltd., 1967. - P. 1-64.

Magaloni B., Kricheli R. Political order and one-party rule // Annual review of political science. - Palo Alto, 2010. - Vol. 13. - P. 123-143.

Magaloni B. Voting for autocracy: Hegemonic party survival and its demise in Mexico. Cambridge, UK: Cambridge univ. press, 2006. -296 p.

Makarenko B. The role of elections in democracy // Democracy in a Russian mirror / Ed. by A. Przeworski. - N.Y.: Cambridge univ. press, 2015. - P. 130-146.

Maraval J.M. Elections and the challenge of more democracy // Democracy in a Russian Mirror / Ed. by A. Przeworski. - N.Y.: Cambridge univ. press, 2015. - P. 147-172.

Pasquino P. Democracy: Ancient and modern, good and bad // Democracy in a Russian Mirror / Ed. by A. Przeworski. - N.Y.: Cambridge univ. press, 2015. - P. 110-129.

Pasquino P. Emmanuel Sieyes, Benjamin Constant et le «gouvernement des modernes». Contribution a' l'histoire du concept de representation politique // Revue francaise de science politique. - Paris, 1987. - Vol. 3, N 7 (2). - P. 214-229.

Political parties and political development / Ed. by J. LaPalombara, M. Weiner. Princeton: Princeton univ. press, 1966. $-487 \mathrm{p}$.

Przeworski A. Democracy and the market: Political and economic reforms in Eastern Europe and Latin America. - Cambridge: Cambridge univ. press, 1991. - $210 \mathrm{p}$.

Przeworski A. Minimalist conception of democracy: A defense // Democracy's value / I. Shapiro, C.H. Cordon (eds). - Cambridge: Cambridge univ. press, 1999. - P. 23-55.

Przeworski A. «Non-Western Democracies» in the West // Democracy in a Russian mirror / Ed. by A. Przeworski. - N.Y.: Cambridge univ. press, 2015. - P. 212-228.

Rustow D. Transitions to democracy: Towards a dynamic model // Comparative politics. - N.Y., 1970. - N 2. - P. 337-363. 
Sartori G. Parties and party systems: A framework for analysis. - N.Y.: Cambridge univ. press, 1976. $-383 \mathrm{p}$.

Schmitter Ph., Karl T.L. What democracy is... and is not // Journal of democracy. Wash., DC, 1991. - Vol. 2, N 3. - P. 75-88.

Schumpeter J. Capitalism, socialism and democracy. - N.Y.: Harper and Row, 1975. $431 \mathrm{p}$.

Shugart M., Carey J. Presidents and assemblies: Constitutional design and electoral dynamics. - Cambridge: Cambridge univ. press, 1992. - $332 \mathrm{p}$.

Stokes D.E. Spatial models of party competition // American political science review. Cambridge, 1963. - Vol. 57, N 2. - P. 368-377.

Taagapera $R$. The tailor of Marrakesh: Western electoral system advice to emerging democracies // CSD Working Papers. - Irvine, CA, 1997. - Mode of access: https://escholarship.org/uc/item/7w39027t (Accessed: 02.11.2018.)

The prospects \& limits of deliberative democracy // Daedalus. - Cambridge, MA, 2017. Vol. 146, N 3, Summer. - P. 28-38.

Urbinati $N$. Democracy disfigured: Opinion, truth and the people. - Cambridge, MA: Harvard univ. press, 2014. $-320 \mathrm{p}$. 